\title{
Innovative anaerobic upflow sludge blanket filtration combined bioreactor for nitrogen removal from municipal wastewater
}

\author{
${ }^{1}$ *H. Khorsandi; ${ }^{2}$ H. Movahedyan; ${ }^{2}$ B. Bina; ${ }^{2}$ H. Farrokhzadeh \\ ${ }^{1}$ Department of Environmental Health Engineering, Urmia University of Medical Sciences, Urmia, Iran \\ ${ }^{2}$ Department of Environmental Health Engineering, Isfahan University of Medical Sciences, Isfahan, Iran \\ Received 18 February 2010; $\quad$ revised 14 November 2010; accepted 1 February 2011; available online 1 March 2011
}

\begin{abstract}
In this research, a novel laboratory scale anaerobic/upflow sludge blanket filtration combined bioreactor was designed and operated to improve the efficiency of the upflow sludge blanket filtration process for the simultaneous removal of phosphorus and nitrogen from wastewater. The anaerobic/upflow sludge blanket filtration technique was developed by adding an anaerobic reactor to its influent and operated by varying the main process parameters in order to gain the optimum conditions. The results showed that biological removal efficiency of nitrogen and preservation of sludge blanket strongly depend on wastewater characteristics, hydraulic retention time, sludge age and process controlling parameters. The combined bioreactor performed a total nitrogen removal efficiency of $96.6 \%$ with the sludge age of 25 days, total hydraulic retention time of $24 \mathrm{~h}$ and optimum "chemical oxygen demand/nitrogen/phosphorus" ratio of 100/ 5/1. This ratio also improved the compaction quality of sludge blanket in the upflow sludge blanket filtration clarifier. The average specific nitrification and denitrification rates occurred during the process can be expressed as $4.43 \mathrm{mg}$ NOx$\mathrm{N}$ produced/g VSS.d and $5.50 \mathrm{mg}$ NOx-N removed/g VSS.d at the optimum ratio, respectively. To avoid sludge rising due to denitrification process, the optimum total hydraulic retention time of 16 to $24 \mathrm{~h}$ was achieved based on the effluent quality. This study suggested that the anaerobic/upflow sludge blanket filtration bioreactor at the optimum operational conditions can be an effective process for removal of nutrients from municipal wastewater.
\end{abstract}

Keywords: Bioreactor; Municipal wastewater; Nutrients; Upflow sludge blanket filtration

\section{INTRODUCTION}

Biological nitrogen and phosphorus removal from wastewater is an effective approach for prevention of eutrophication in water bodies (Lu and Huang, 2010; Babel et al., 2009). The adverse effects of eutrophication have frequently been discussed by many authors and vary from decrease in aesthetic and quality depletion of the affected receiving water bodies to increase in treatment costs (Gerardi, 2002; Hu et al., 2003; Seviour et al., 2003; Yang et al., 2005; Zaman, 2010). Biological removal of nitrogen and phosphorus is usually integrated in wastewater treatment systems whenever treated effluent is to be discharged to sensitive receiving water bodies or to be exploited for reuse (Tchobanoglus et al., 2003; WEF et al., 2006; Akpor et al., 2008; Suthar and Singh, 2008; Hooshyari, 2009). There are several varieties of configurations such

\footnotetext{
\*Corresponding Author Email: hassankhorsandi@yahoo.com
} Tel.: +984412752 305; Fax: +98 4412770047 as the University of Cape Town treatment process and modified bardenpho in combined nitrogen and phosphorus removal processes based on influent characteristics, effluent limits (WEF et al., 2006) and desired operational conditions. All of these configurations consist of the same basic anaerobic/ anoxic/aerobic components to achieve nitrification/ denitrification and enhanced biological phosphorus uptake. In these configurations, chemical compounds addition and filtration of final effluent through the sand or other media are required for the removal of particulate matter when low nitrogen and phosphorus in the effluent are desired (Tchobanoglus et al., 2003; Priadi et al., 2011).

Nitrification and denitrification are the well known biological processes which primarily remove nitrogen from its solutions (Tchobanoglus et al., 2003). Nitrification is the two-step biological conversion of ammonia to nitrite and then to nitrate under aerobic 
conditions by one group of autotrophic bacteria include nitrosomonas and nitrobacter. Denitrification involves the biological reduction of nitrate to nitrogen gas in the absence of dissolved oxygen under anoxic conditions by a wide range of heterotrophic bacteria species, for example achromobacter, bacillus and flavobacterium and some autotrophic bacteria, such as nitrosomonas europaea (Tchobanoglus et al., 2003; Gerardi, 2006; Henze et al., 2008; Abdulsalam et al., 2011).

The upflow sludge blanket filtration (USBF) process is a novel configuration that incorporates an anoxic selector zone, an aeration unit and an upflow sludge blanket filtration clarifier in one integrated bioreactor (Wang et al., 2008; Rajakumar et al., 2011). In the USBF plant, wastewater enters the anoxic compartment where it mixes with activated sludge recycled from the bottom of the clarifier. The mixed liquor eventually underflows into the aerobic compartment. After aeration, a stream of the mixed liquor enters the bottom of a prism or cone-shaped clarifier and, as it rises, upward velocity decreases until the flocs of cells become stationary. Then, sludge flocs are separated from liquid by upflow sludge blanket filtration and clear effluent overflows into a collection trough and is discharged from the system (Su et al., 2004; Wang et al., 2008). A recently published paper about USBF process indicates that the efficiency of single stage USBF for nitrogen removal is about $80.2 \%$ at the aeration time of $6 \mathrm{~h}$ (Mahvi et al., 2008). Due to undesired efficiency of single stage USBF for phosphorous removal (Mahvi et al., 2008; Wang et al., 2008), the novel Anaerobic/USBF combined bioreactor was developed to promote the simultaneous removal of nitrogen and phosphorous from wastewaters. The objective of this paper is nitrogen removal with the anaerobic/USBF combined bioreactor. It is worth something as prior to this research, no study has been published about biological removal of nutrients by anaerobic/USBF process technique.
This research was conducted in pilot center of Isfahan University of Medical Sciences in Isfahan, Iran during 2009.

\section{MATERIALS AND METHODS}

\section{Experimental setup}

The experiments were conducted using a laboratory scale Anaerobic/ USBF combined bioreactor (Fig. 1) and the operational parameters for the lab-scale Anaerobic/USBF combined bioreactor are listed in Table 1.

In the Anaerobic/USBF process technique, anaerobic/aerobic configuration was installed as an integrated unit for performance of enhanced biological phosphorus removal (EBPR). The anoxic zone was built for dissimilarity nitrate reduction by denitrifier species, such as Achromobacter, Acintobacter and phosphorus uptake by polyphosphate accumulating organisms e.g., Pseudomonas and Enterobacter (Hu et al, 2002; Carvalho et al., 2007). Function of the aeration zone was nitrification and phosphorus luxury uptake.

The recycling sludge from the USBF clarifier was directed to the anoxic zone by a submersible pump. The amount of return activated sludge (RAS) from the clarifier was controlled and monitored by a full automatic timer, which in turn controlled the amount and time of sludge returning.

Mixed-liquor from anoxic zone was recycled to anaerobic reactor by an Etatron pump for EBPR implementation. The RAS and anoxic recirculation rates were typically four and two times respectively as many as the influent flow rate.

Anaerobic/USBF combined bioreactor was placed into a water bath equipped with aquarium heaters and thermocouple to operate at the constant temperature of $28 \pm 1^{\circ} \mathrm{C}$. Required air for aeration and mixing in the aerobic zone was supplied by the Hailea air compressor with maximum discharge of $90 \mathrm{~L} / \mathrm{min}$ and injected via three parallel tube diffusers. The airflow rate was

Table 1: Operational parameters for the lab-scale Anaerobic/USBF combined bioreactor

\begin{tabular}{|c|c|c|c|c|}
\hline Parameters & $\begin{array}{c}\text { Anaerobic } \\
\text { reactor }\end{array}$ & $\begin{array}{l}\text { Anoxic } \\
\text { reactor }\end{array}$ & $\begin{array}{c}\text { Aerobic } \\
\text { reactor }\end{array}$ & $\begin{array}{c}\text { USBF } \\
\text { clarifier }\end{array}$ \\
\hline Volume (L) & 3 & 6 & 9 & 2 \\
\hline Flow rate (L/day) & & & $10-60$ & \\
\hline HRT (h) & $1.2-7.2$ & $2.4-14.4$ & 3.6-21.6 & $0.8-4.8$ \\
\hline SRT (day) & - & - & $10-30$ & - \\
\hline Average MLSS (mg/L) * & 2605 & 3290 & 3735 & 6200 \\
\hline Average MLVSS (mg/L) * & 2115 & 2575 & 2865 & - \\
\hline
\end{tabular}

*At the optimum COD/N/P ratio of 100/5/1 
regulated with three manual valves to supply the dissolved oxygen demand (DO) at a concentration of $4 \pm$ $0.5 \mathrm{mg} / \mathrm{Lin}$ the mixed-liquor of aerobic zone. The mixing of anaerobic and anoxic reactor contents was carried out by a mixer with the speed of $32 \mathrm{rpm}$.

\section{Operational procedure}

The synthetic wastewater containing glucose as the main organic source, $\mathrm{NH}_{4} \mathrm{HCO}_{3}$ as nitrogen (N) source and $\mathrm{KH}_{2} \mathrm{PO}_{4}$ and $\mathrm{K}_{2} \mathrm{HPO}_{4}$ as phosphorus (P) sources was introduced to the system during operation. The synthetic wastewater characteristics have been depicted in Table 2 (Smolders et al., 1994; Hu et al., 2003; Kishida et al., 2006). The sludge which obtained from Isfahan municipal wastewater treatment plant was used as a seed. The composition of ingredients in synthetic wastewater was determined on the basis of desired chemical oxygen demand (COD) concentration, $\mathrm{COD} / \mathrm{N}$ and COD/P ratios. In order to evaluate the effects of $\mathrm{COD} / \mathrm{N} / \mathrm{P}$ ratios on the efficiency of the system and reach the optimum ratio, $\mathrm{COD} / \mathrm{N}$ and COD/P ratios were ranged from 25 to 6 and from 100 to 30 respectively, based on constant COD concentration of $750 \mathrm{mg} / \mathrm{L}$.

Prepared synthetic wastewater was continuously pumped into the Anaerobic/USBF combined bioreactor with the flow rate of $20 \mathrm{~L} /$ dayunder the aforementioned conditions. Using this flow rate resulted in the hydraulic retention time (HRT) of $3.6 \mathrm{~h}, 7.2 \mathrm{~h}$ and $10.8 \mathrm{~h}$, in the anaerobic, anoxic and aerobic reactors, respectively. In the series of experiments assessing the influence of various HRT and COD/N/P ratios on system efficiency, the sludge retention time (SRT) of 25 days was maintained. At the optimum COD/N/P ratio, overall HRT was set variably from 12 to $48 \mathrm{~h}$ to select the optimum HRT.
Mass balance calculations were developed to determine the actual changes of nitrogen and other parameters in each reactor on the basis of influent, effluent and return flows.

At the end of experiments, to estimate the values of the selected kinetic parameters, continuous feeding of the system was interrupted and the system was run under the batch mode by hydraulic isolation of each single tank. Instant addition of nitrate (about 30 $\mathrm{mg} \mathrm{NO}_{3}-\mathrm{N} / \mathrm{L}$ ) and organic substrate (200 mg COD/ $\mathrm{L})$ took place directly in the anoxic compartment. At the same time, ammonia was added in excess amount (30 mg NH$-\mathrm{N} / \mathrm{L}$ ) into the aerobic tank. Samples of mixed liquor were taken from each reactor at fixed time intervals and were immediately analyzed (Warner et al., 1986; Harremoës and Sinkjaer 1995; Ekama and Wentzel 1999; Dincer and Kargi 2000; Kapagiannidis et al., 2006).

\section{Sampling and Analysis}

The system was monitored for about one month by allowing the synthetic wastewater to reach steady state conditions and then operated in seven months. At least three runs of steady state data were collected

Table 2: Composition of synthetic wastewater used in this study

\begin{tabular}{ll}
\hline Chemicals & \multicolumn{1}{c}{ Concentrations } \\
\hline $\mathrm{C}_{6} \mathrm{H}_{12} \mathrm{O}_{6} \cdot \mathrm{H}_{2} \mathrm{O}$ & $773.43 \mathrm{mg} / \mathrm{L}$ \\
$\mathrm{NH}_{4} \mathrm{HCO}_{3}$ & variable as COD/N \\
$\mathrm{KH}_{2} \mathrm{PO}_{4}$ & variable as COD/N \\
$\mathrm{K}_{2} \mathrm{HPO}_{4}$ & variable as COD/N \\
$\mathrm{MgSO}_{4} \cdot 7 \mathrm{H}_{2} \mathrm{O}$ & as $\mathrm{Mg} / \mathrm{P}=0.56$ \\
$\mathrm{CaCl}_{2} \cdot 2 \mathrm{H}_{2} \mathrm{O}$ & as $\mathrm{Ca} / \mathrm{P}=0.32$ \\
$\mathrm{FeCl}_{3} \cdot 6 \mathrm{H}_{2} \mathrm{O}$ & as $\mathrm{Fe} / \mathrm{COD}=0.5 / 100$ \\
Trace elements * & $0.5 \mathrm{~mL} / \mathrm{L}$ \\
\hline
\end{tabular}

*Trace element compounds include: $\mathrm{FeCl}_{3} .6 \mathrm{H} 2 \mathrm{O} 1.5 \mathrm{~g} / \mathrm{L}, \mathrm{H}_{3} \mathrm{BO}_{3} 0.15 \mathrm{~g}$ $\mathrm{L}, \mathrm{CuSO}_{4} .5 \mathrm{H}_{2} \mathrm{O} 0.03 \mathrm{~g} / \mathrm{L}$, KI $0.03 \mathrm{~g} / \mathrm{L}, \mathrm{MnCl}_{2} .4 \mathrm{H}_{2} \mathrm{O} 0.12 \mathrm{~g} / \mathrm{L}$, $\mathrm{NaMoO}_{4} \cdot 2 \mathrm{H}_{2} \mathrm{O} 0.06 \mathrm{~g} / \mathrm{L}, \mathrm{ZnSO}_{4} \cdot \mathrm{H}_{2} \mathrm{O} 0.12 \mathrm{~g} / \mathrm{L}, \mathrm{CoCl}_{2} \cdot 6 \mathrm{H}_{2} \mathrm{O} 0.15 \mathrm{~g} / \mathrm{L}$.

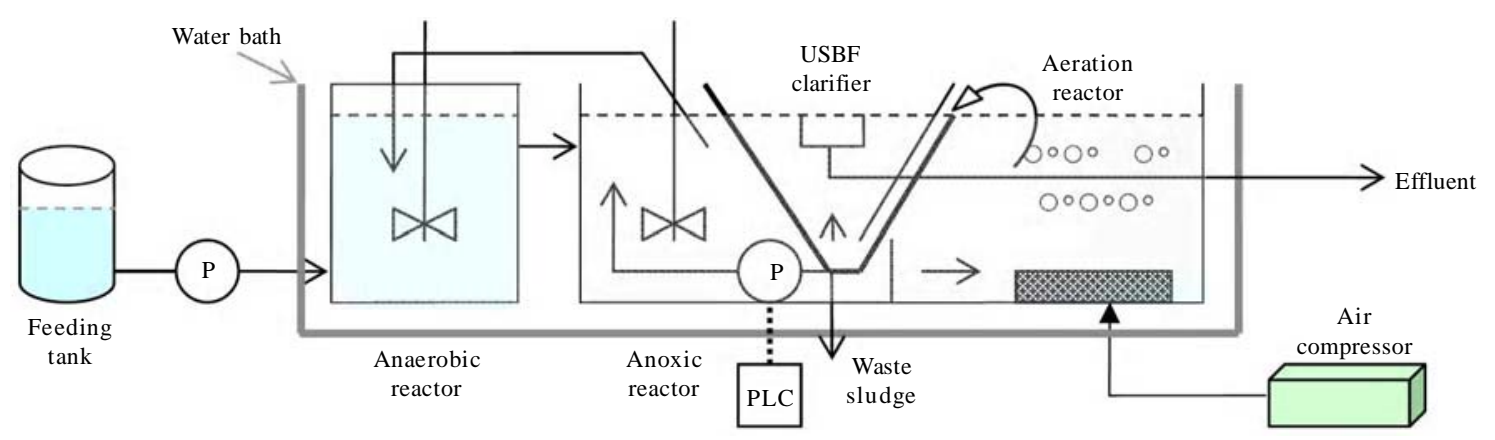

Fig. 1: Schematic diagram of the lab-scale Anaerobic/USBF combined bioreactor 
from each reactor during each phase of experiments to characterize each of them.

Samples were collected from influent, effluent and sampling port of each reactor. Temperature, DO and $\mathrm{pH}$ were daily measured in each reactor immediately before sampling. DO measurements were carried out using a YSI 55 DO meter (YSI Company Inc., USA) and a Schott $\mathrm{pH}$ meter model CG-824 was used for pH analysis.(Schott UK Ltd). The samples were analyzed immediately after centrifuge. Soluble chemical oxygen demand (sCOD), ammonium $\left(\mathrm{NH}_{4}-\right.$ $\mathrm{N})$, nitrate $\left(\mathrm{NO}_{3}-\mathrm{N}\right)$, nitrite $\left(\mathrm{NO}_{2}-\mathrm{N}\right)$, soluble phosphorus $\left(\mathrm{PO}_{4}-\mathrm{P}\right)$, mixed liquor suspended solid (MLSS) and mixed liquor volatile suspended solid (MLVSS) were analyzed in accordance with standard methods for the examination of water and wastewater (APHA, et al., 2005).

\section{RESULTS AND DISCUSSION}

The novel Anaerobic/USBF combined bioreactor was developed to promote the simultaneous removal of nitrogen and phosphorous from wastewater. At this paper, it was focused on evaluation of nitrogen removal using Anaerobic/USBF combined bioreactor.

Nitrogen removal was carried out using preanoxic denitrification. In order to evaluate the influence of $\mathrm{COD} / \mathrm{N} / \mathrm{P}$ ratios on system efficiency and reach to the optimum ratio, the COD/N ratios of $20,16,14,12,10,8$ and 6 were examined at the constant COD of $750 \mathrm{mg} / \mathrm{L}$, total HRT of $24 \mathrm{~h}$ and SRT of 25 days. The average total Kjeldahl nitrogen (TKN) and average total nitrogen (TN) removal efficiency at varying $\mathrm{COD} / \mathrm{N}$ ratio are shown in Figs. 2 and 3. It can be observed in Figs. 2 and

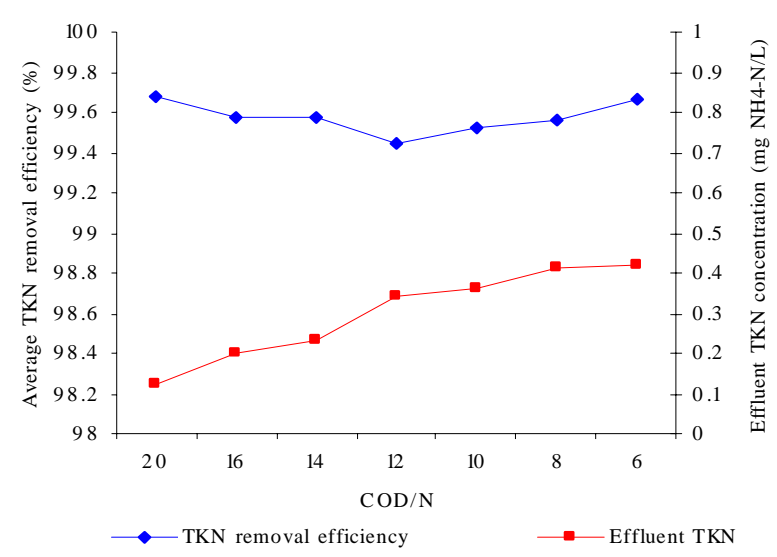

Fig. 2: The average TKN removal efficiency versus COD/N variations $(\mathrm{HRT}=24 \mathrm{~h}, \mathrm{SRT}=25$ days)
3 that the average TKN removal efficiency and the average effluent TKN were approximately constant but the TN removal efficiency was decreased with decreasing $\mathrm{COD} / \mathrm{N}$ ratio. The results also indicated that the average total nitrogen and the average TKN removal efficiency are $96.61 \%$ and $99.68 \%$ respectively, which was obtained at the optimum COD/N/P ratio of 100/5/1 and the compaction of sludge blanket at this ratio was better than that in other ratios.

Tay et al. (2003) examined the effects of COD/N/P ratio on nitrogen and phosphorus removal in a single upflow fixed-bed filter provided with anaerobic, anoxic, and aerobic conditions. The authors revealed that phosphorus removal efficiency was affected more by its own concentration than that of COD and $\mathrm{N}$ concentrations, while nitrogen removal efficiency was unaffected bydifferent phosphorus concentrations. At the COD/N/P ratio of 300/5/1, both nitrogen and phosphorus were effectively removed using the filter, with removal efficiencies of $87 \%$ and $76 \%$, respectively (Tay et al., 2003).

Figs. 4 and 5 illustrate the average TKN and average TN removal efficiency in the anaerobic/USBF combined bioreactor at the optimum COD/N/P ratio of 100/5/1 respectively. The similar average removal efficiency (H”33.2 \%) was observed in the anaerobic unit for both TKN and TN. However, the highest average removal efficiency for TKN in aerobic unit was found to be 94.7 $\%$ as compared to highest average removal efficiency for TN in anoxic unit (60.01\%). The above results confirmed that nitrification and denitrification processes have been taken place in the aerobic and anoxic reactors respectively.

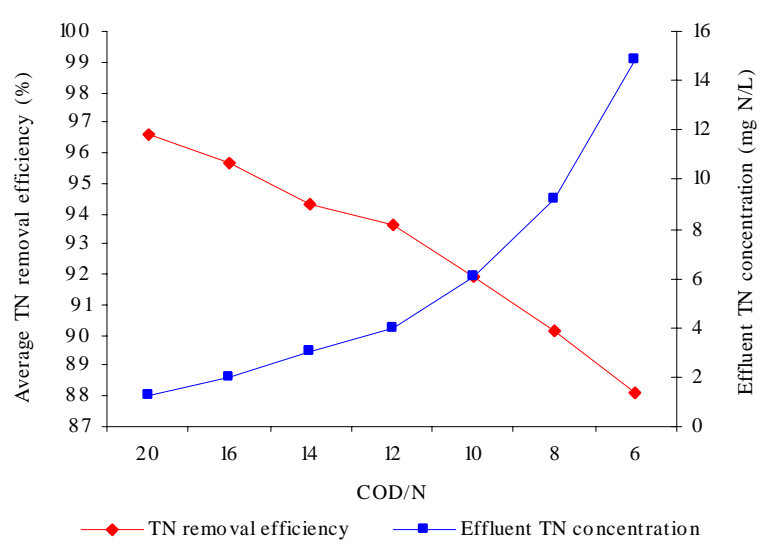

Fig. 3: The average TN removal efficiency versus COD/N variations $(\mathrm{HRT}=24 \mathrm{~h}, \mathrm{SRT}=25$ days) 
Nitrification rates at different aerobic TKN loading rates are shown in Fig. 6. Nitrification rate has increased with increasing ammonium loading. By a TKN loading rate of $18.18 \mathrm{~g} \mathrm{NH}_{4}-\mathrm{N} / \mathrm{m}^{3}$.d, nitrification rate at the optimum ratio was $17.88 \mathrm{~g} \mathrm{NH}_{4}-\mathrm{N}$ removed $/ \mathrm{m}^{3}$.d and $12.688 \mathrm{~g} \mathrm{NO}_{\mathrm{x}}-\mathrm{N}$ produced $/ \mathrm{m}^{3}$.d. Because some of the aerobic loading rate was consumed for cell anabolism, nitrification as $\mathrm{g} \mathrm{NO}_{\mathrm{X}}-\mathrm{N}$ produced $/ \mathrm{m}^{3}$.d was less than that of as $\mathrm{g} \mathrm{NH}-\mathrm{N}$ removed $/ \mathrm{m}^{3}$.d.

During the experimental work, the average MLSS and MLVSS concentration were $3735 \mathrm{mg} / \mathrm{L}$ and 2865 $\mathrm{mg} / \mathrm{L}$ at the optimum ratio, respectively. Thus, the average specific nitrification rate in the aerobic reactor can be expressed as $4.428 \mathrm{mg} \mathrm{NO}$-N produced/g VSS.d at the optimum ratio. Nevertheless the maximum specific nitrification rate in the aerobic reactor was equal to $33.912 \mathrm{mg} \mathrm{NO}-\mathrm{N}$ produced/g VSS.d at the COD/N ratio of 6.

According to experiments and Table 1, the average specific denitrification rate was $5.5 \mathrm{mg} \mathrm{NO}-\mathrm{N}$ removed/ g VSS.d at the optimum ratio.

The results obtained from the experiments under batch condition for determination of kinetic parameters of nitrification and denitrification processes were demonstrated in Figs.7 and 8. The maximum specific nitrification rate (SNR) and half saturation constant for ammonium-nitrogen were $1.05 \mathrm{mg}$ oxidized $\mathrm{NH}_{4}-\mathrm{N}$ / g VSS.h and $2.59 \mathrm{mg} / \mathrm{L}$, respectively. Fig. 7 indicates that high $\mathrm{NH}_{4}-\mathrm{N}$ concentrations ensure the process description by zero order kinetics. As nitrogen becomes scarce i.e. $\mathrm{NH}_{4}-\mathrm{N}$ concentrations below $10 \mathrm{mg} / \mathrm{L}$, the reaction is described by transition between zero and first order kinetics. Fig. 8 confirms that denitrification

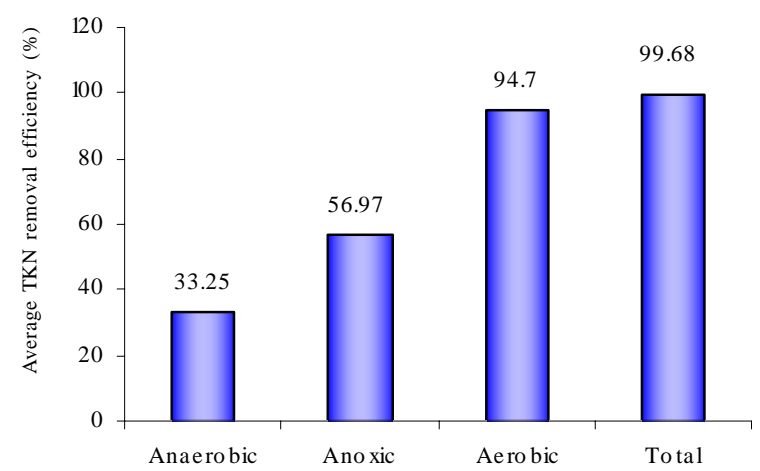

Fig. 4: The average TKN removal efficiency in the reactors at the optimum COD/N/P ratio $(\mathrm{HRT}=24 \mathrm{~h}, \mathrm{SRT}=25$ days) process follows zero order kinetics with the specific denitrification rate (SDNR) of $3.26 \mathrm{mg}$ reduced $\mathrm{NO}_{3}-\mathrm{N} /$ g VSS.h.

Nitrifying bacteria, such as Nitrosomonas and Nitrobacter exhibit different substrate concentration sensitivities. Media containing low substrate concentrations (10 $\mathrm{mg} \mathrm{NH}_{4} / \mathrm{L}$ ) can give larger most probable number of ammonia oxidizers than media containing higher $\mathrm{NH}_{4}$ concentrations. Also, ammonia oxidation is inhibited at high substrate concentrations (Suwa et al., 1994; Princic et al., 1998; Gujer, 2010). Based on mentioned principles, nitrogen removal decreases as the influent TKN/COD ratio increases (Henze et al., 2008), which is in agreement with the results obtained from this study (Figs. 2-8).

Biological reduction of nitrate to nitrite and $\mathrm{N}_{2}$ gas requires a suitable electron donor. The rate of denitrification depends primarily upon the nature and concentration of the organic matter present as electron donor (Plosz, 2007). It is commonly accepted that denitrification is zero-order with respect to nitrate concentration down to very low levels (Sedlak, 1991).

SRT is one of the significant parameters that affects on biological nutrient removal processes. Fig. 9 illustrates SRT effects on average TN removal efficiency. The efficiency of TN removal increased with increasing SRT.

Under long aerobic SRT, more oxidation of organic matter can be obtained, leading to a higher rate of nitrogen removal (You et al., 2003). However, it may adversely affect the biological removal of phosphorus due to the secondary release of phosphorus because of an increase in endogenous respiration in the aerobic

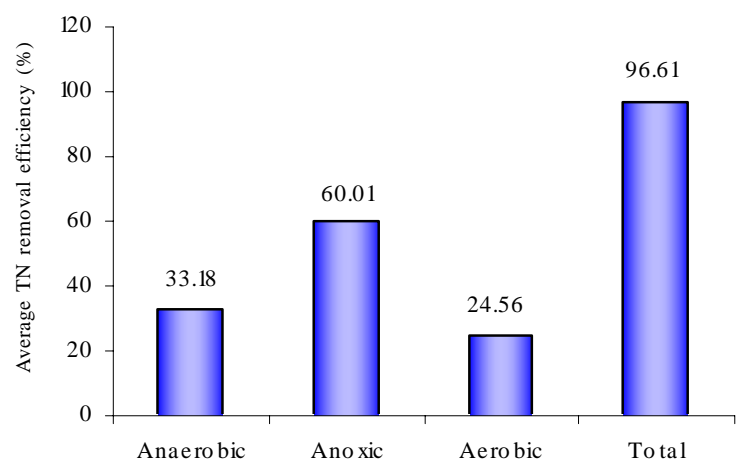

Fig. 5: The average TN removal efficiency in the reactors at the optimum $\mathrm{COD} / \mathrm{N} / \mathrm{P}$ ratio $(\mathrm{HRT}=24 \mathrm{~h}, \mathrm{SRT}=25$ days) 
zone. Hence, optimum SRT ought to be selected according to the most optimal settling condition and desirable efficiency for BNR (You et al., 2003). It has been reported that SRT of 10-12 days is an optimal range for the maximum removal of both $\mathrm{N}$ and $\mathrm{P}$ (Chuang et al., 1997; Kargi and Uygur 2002). The maximum SRT value obtained after 10 days was in conformity with the present studies so that TN and TP removal efficiency were determined $90.4 \%$ and $86.0 \%$ at the sludge age of 10 days. When the sludge age increased to 30 days, these amounts were changed to $96.9 \%$ and $81.33 \%$ respectively.

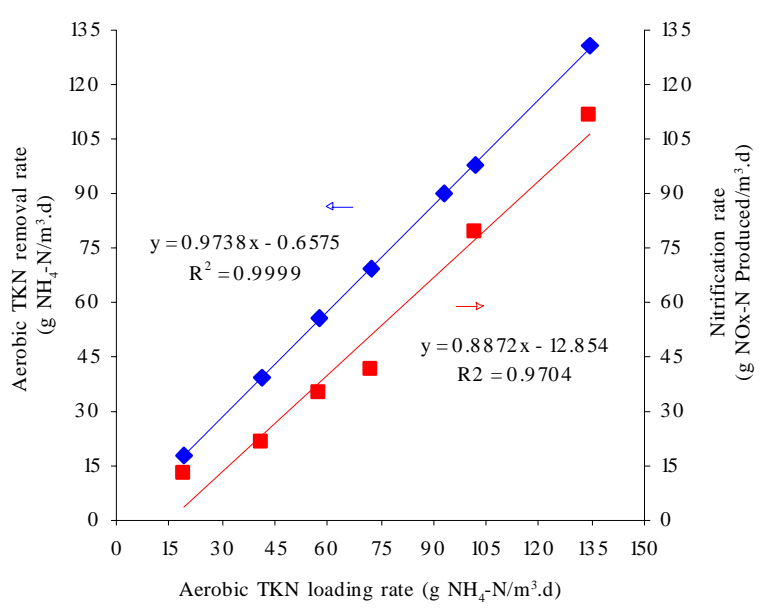

Fig. 6: The average nitrification rates at various aerobic TKN loading rates

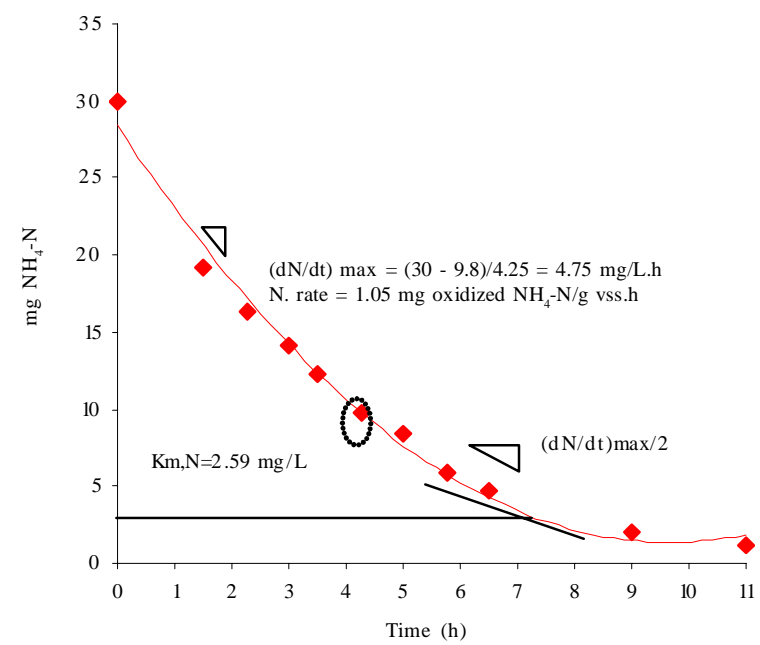

Fig. 7: The maximum specific nitrification rate (SNR) and half saturation constant for ammonium-nitrogen
In order to select optimum HRT, the effect of total HRT on $\mathrm{PO}_{4}-\mathrm{P}, \mathrm{TN}$, sCOD removal efficiency and effluent TSS were examined in the lab-scale Anaerobic/ USBF combined bioreactor. The compaction of sludge blanket for the present study was weak with a total HRT of less than $16 \mathrm{~h}$ and more than $24 \mathrm{~h}$, optimum total HRT can be selected between 16 and $24 \mathrm{~h}$ for this configuration, based on effluent quality (Fig. 10). It was obvious that rising sludge due to denitrification in the USBF clarifier has increased with increasing HRT. This conclusion corresponds with researches on other processes of nutrient removal (Tchobanoglus et al., 2003; WEF et al., 2006; Henze et al., 2008).

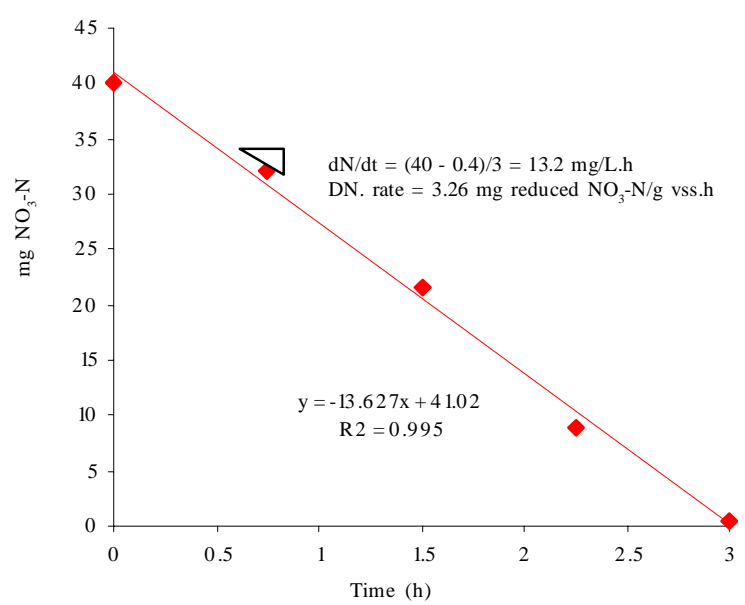

Fig. 8: The specific denitrification rate (SDNR) for nitrate nitrogen

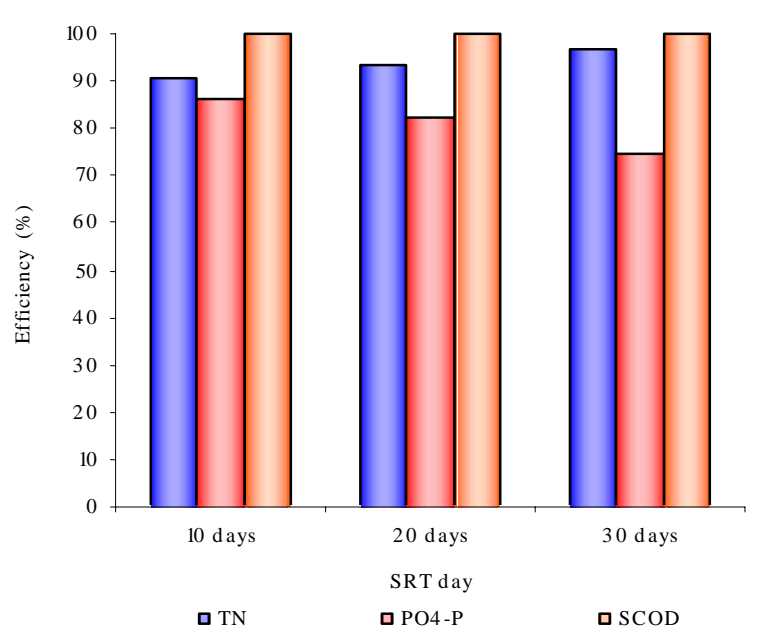

Fig. 9: The average total nitrogen, phosphorus and sCOD removal efficiency at different SRT (HRT=24 h) 


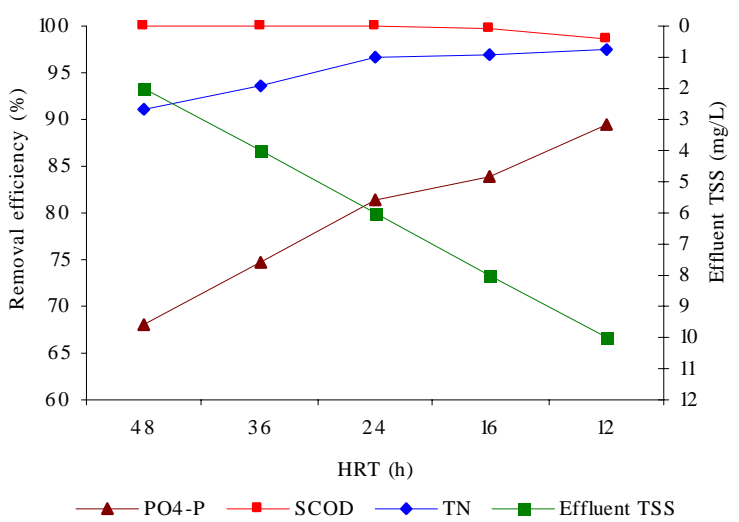

Fig. 10: The effect of total HRT on the average TN, $\mathrm{PO}_{4}-\mathrm{P}$, sCOD and TSS removal efficiency

The influent TKN/COD ratio, clarifier shape and kind of pump strongly affected monotonous sludge recycle, effluent TSS in the USBF clarifier based on operational experiments.

\section{CONCLUSION}

Biological removal efficiency of nitrogen and preservation of sludge blanket strongly depend on wastewater characteristics, HRT, SRT and process control. The combined bioreactor performed a total nitrogen removal efficiency of $96.61 \%$ with a sludge age of 25 days, HRT of $24 \mathrm{~h}$ and optimum COD/N/P ratio of $100 / 5 / 1$. The Anaerobic/USBF combined bioreactor at the optimum conditions can be an effective technology for nitrogen removal from municipal wastewater, but it is not suggested for wastewater containing a high TKN/COD ratio because of rising sludge and disordering blanket in the USBF clarifier.

\section{ACKNOWLEDGEMENTS}

The authors would like to thank the research administration of Isfahan University of Medical Sciences for financial support to carry out this project under grant number 387154. The authors also appreciate the technical contribution of Mr. H. Farrokhzadeh and his assistance in constructing the lab-scale Anaerobic/ USBF combined bioreactor.

\section{REFERENCES}

Abdulsalam, S.; Bugaje, I. M.; Adefila, S. S.; Ibrahim, S., (2011). Comparison of biostimulation and bioaugmentation for remediation of soil contaminated with spent motor oil. Int. J. Environ. Sci. Tech., 8 (1), 187-194 (8 pages).

Akpor, O. B.; Momba, M. N. B.; Okonkwo, J. O.; Coetzee, M. A., (2008). Nutrient removal from activated sludge mixed liquor by wastewater protozoa in a laboratory scale batch reactor. Int. J. Environ. Sci. Tech., 5 (4), $463-470$ (8 pages).

APHA; AWWA; WEF, (2005). Standard methods for the examination of water and wastewater. $21^{\text {st }}$ Ed. American Public Health Association, American Water Works Association and the Water Environment Federation. Washington DC., USA.

Babel, S.; Sae-Tang, J.; Pecharaply, A., (2009). Anaerobic codigestion of sewage and brewery sludge for biogas production and land application. Int. J. Environ. Sci. Tech., 6 (1), 131140 (10 pages).

Carvalho, G.; Lemos, P. C.; Oehmen, A.; Reis, M. A. M., (2007). Denitrifying phosphorus removal: Linking the process performance with the microbial community structure. Water Res., 41 (19), 4383-4396 (14 pages).

Chuang, S. H.; Ouyang, C. F.; Yuang, H. C.; You, S. J., (1997). Effects of SRT and DO on nutrient removal in a combined AS-biofilm process. Water Sci. Tech., 36 (12), 19-27 (9 pages).

Dincer, A. R.; Kargi, F., (2000). Kinetics of sequential nitrification and denitrification processes. Enzyme Microb. Tech., 27 (1-2), 37-42 (6 pages).

Ekama, G. A.; Wentzel, M. C., (1999). Denitrification kinetics in biological $\mathrm{N}$ and $\mathrm{P}$ removal activated sludge systems treating municipal wastewaters. Water Sci. Tech., 39 (6), 66-79 (14 pages).

Gerardi, M. H., (2002). Nitrification and denitrification in the activated sludge process. Wiley-Interscience, New York, 110 (10 pages).

Gerardi, M. H., (2006). Wastewater bacteria. John Wiley and Sons, Inc., Hoboken, New Jersey, 77-101 (25 pages).

Gujer, W., (2010). Nitrification and me - A subjective Rev. Water Res., 44, 1-19 (19 pages).

Harremoës, P.; Sinkjaer, O., (1995). Kinetic interpretation of nitrogen removal in pilot scale experiments. Water Res., 29 (3), 899-905 (7 pages).

Henze, M.; Van Loosdrecht, M. C. M.; Ekama, G. A.; Brdjanovic, D., (2008). Biological wastewater Treatment (Principles, Modeling and Design). IWA, 155-178 (24 pages).

Hooshyari, B.; Azimi, A.; Mehradadi, N., (2009). Kinetic analysis of enhanced biological phosphorus removal in a hybrid integrated fixed film activated sludge process. Int. J. Environ. Sci. Tech., 6 (1), 149-158 (10 pages).

Hu, J. Y.; Ong, S. L.; Ng, W. J.; Lu, F.; Fan, X. J., (2003). A new method for characterizing denitrifying phosphorus removal bacteria by using three different types of electron acceptors. Water Res., 37 (14), 3463-3471 (9 pages).

Hu , Z. R.; Wentzel, M. C; Ekma, G. A., (2002). Anoxic growth of phosphate-accumulating organisms (PAOs) in biological nutrient removal activated sludge systems. Water Res., 36 (19), 4927-4937 (11 pages).

Kapagiannidis, A. G.; Vaiopoulou, E. and Aivasidis, A., (2006). Determination of kinetic parameters in a pilot scale BNR system treating municipal wastewater. Glob. NEST J., 8 (1), 68-74 (7 pages).

Kargi, F.; Uygur, A., (2002). Nutrient removal performance of a sequencing batch reactor as a function of the sludge age. Enzyme Microb. Tech., 31 (6), 842-847 (6 pages). 
Kishida, N.; Kim, J.; Tsuneda, S.; Sudo, R., (2006). Anaerobic/ oxic/anoxic granular sludge process as an effective nutrient removal process utilizing denitrifying polyphosphateaccumulating organisms. Water Res., 40 (12), 2303-2310 (8 pages).

Lu, X. M.; Huang, M. S., (2010). Nitrogen and phosphorus removal and physiological response in aquatic plants under aeration conditions. Int. J. Environ. Sci. Tech., 7 (4), 665674 (10 pages).

Mahvi, A. H.; Nabizadeh, R.; Pishrafti, M. H.; Zarei, Th., (2008). Evaluation of single stage USBF in removal of nitrogen and phosphorus from wastewater. Eur. J. Sci. Res., 23 (2), 204-211 (8 pages).

Plosz, B. Gy., (2007). Optimization of the activated sludge anoxic reactor configuration as a means to control nutrient removal kinetically. Water Res., 41 (8), 1763-1773 (11 pages).

Priadi, C.; Ayrault, S.; Pacini, S.; Bonte, P., (2011). Urbanization impact on metals mobility in riverine suspended sediment: Role of metal oxides. Int. J. Environ. Sci. Tech., 8 (1), 1-18 (18 pages).

Princic, A.; Mahne, I.; Megusar, F.; Paul, E. A.; Tiedje, J. M., (1998). Effects of $\mathrm{pH}$ and oxygen and ammonium concentrations on the community structure of nitrifying bacteria from wastewater. Appl. Environ. Microbiol., 64 (10), 3584-3590 (7 pages).

Rajakumar, R.; Meenambal, T.; Rajesh Banu, J.; Yeom, I. T., (2011). Treatment of poultry slaughterhouse wastewater in upflow anaerobic filter under low upflow velocity. Int. J. Environ. Sci. Tech., 8 (1), 149-158 (10 pages).

Sedlak, R., (1991). Phosphorus and nitrogen removal from municipal wastewater: principles and practice. $2^{\text {nd }}$ Ed., Lewis Publishers, New York, 43-88 (46 pages).

Seviour, R. J.; Mino, T.; Onuki, M., (2003). The microbiology of biological phosphorus removal in activated sludge systems. FEMS Microbiol. Rev., 27 (1), 99-127 (29 pages).

Smolders, G. J. F.; Van der Meiji, J.; Van Loosdrecht, M. C. M.; Heijnen, J. J., (1994). Stoichiometric model of the aerobic metabolism of the biological phosphorus removal process. Biotech. Bioeng., 44 (7), 837-848 (12 pages).
Su, S. T.; Wu, R. M.; Lee, D. J., (2004). Blanket dynamics in upflow suspended bed. Water Res., 38 (1), 89-96 (8 pages).

Suthar, S.; Singh, S., (2008). Vermicomposting of domestic waste by using two epigeic earthworms (Perionyx excavatus and Perionyx sansibaricus). Int. J. Environ. Sci. Tech., 5 (1), 99-106 (8 pages).

Suwa, Y.; Imamura, Y.; Suzuki, T.; Tashiro, T.; Urushigawa, Y., (1994). Ammonium-oxidizing bacteria with different sensitivies to (NH4)2SO4 in activated sludges. Water Res., 28 (7) 1523-1532 (10 pages).

Tay, J. H.; Chui, P. C.; Li, H., (2003). Influence of COD:N:P ratio on nitrogen and phosphorus removal in fixed-bed filter. J. Environ. Eng., 129 (4), 285-290 (6 pages).

Tchobanoglus, G.; Burton, F. L.; Stensel, H. D., (2003). Wastewater engineering (treatment and reuse). $4^{\text {th }}$ Ed., McGraw- Hill Inc., 799-816 (18 pages).

Wang, L. K.; Shammas, N. K.; Hung, Y. T., (2008). Advanced biological treatment processes. Humana Pr Inc., New York, USA, 365-408 (44 pages).

Warner, A. P. C.; Ekama, G. A.; Marais G. V. R., (1986). The activated sludge process-IV: Application of the general kinetic model to anoxic-aerobic digestion of waste activated sludge. Wat. Res., 20 (8), 943-958 (16 pages).

WEF; ASCE; EWRI, (2006). Biological nutrient removal operation in wastewater treatment plants. McGraw-Hill Inc., 106-125 (20 pages).

Yang, Y.; Inamoria, Y.; Ojimab, H.; Machiic, H.; Shimizud, Y., (2005). Development of an advanced biological treatment system applied to the removal of nitrogen and phosphorus using the sludge ceramics. Water Res., 39 (20), 4859-4868 (10 pages).

You, S. J.; Hsu, C. L.; Chuangc, S. H; Ouyanga, C. F., (2003). Nitrification efficiency and nitrifying bacteria abundance in combined AS-RBC and $\mathrm{A}^{2} \mathrm{O}$ systems. Water Res., 37 (10), 2281-2290 (10 pages).

Zaman, A. U., (2010). Comparative study of municipal solid waste treatment technologies using life cycle assessment method. Int. J. Environ. Sci. Tech., 7 (2), 225-234 (10 pages).

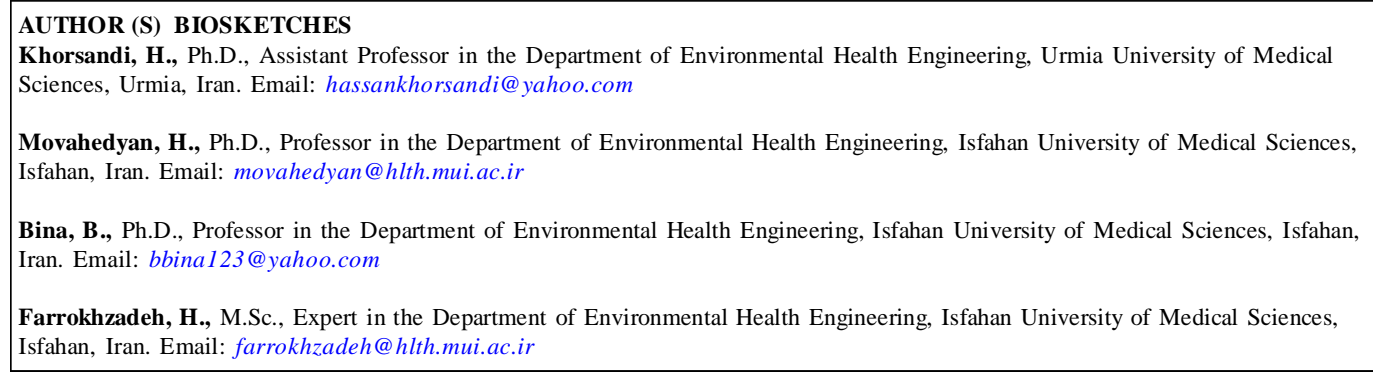

Movahedyan, H., Ph.D., Professor in the Department of Environmental Health Engineering, Isfahan University of Medical Sciences, Isfahan, Iran. Email: movahedyan@hlth.mui.ac.ir

Bina, B., Ph.D., Professor in the Department of Environmental Health Engineering, Isfahan University of Medical Sciences, Isfahan, Iran. Email: bbina123@yahoo.com

Farrokhzadeh, H., M.Sc., Expert in the Department of Environmental Health Engineering, Isfahan University of Medical Sciences, Isfahan, Iran. Email: farrokhzadeh@hlth.mui.ac.ir

How to cite this article: (Harvard style)

Khorsandi, H.; Movahedyan, H.; Bina, B.; Farrokhzadeh, H., (2011). Innovative anaerobic upflow sludge blanket filtration combined bioreactor for nitrogen removal from municipal wastewater. Int. J. Environ. Sci. Tech., 8 (2), 417-424. 